\title{
Detection of Protease Activity by Concentration Quenching-Based Substrates
}

\author{
Daisuke Sato, Wu Zhe, and Tamaki Kato \\ Graduate School of Life Science and Systems Engineering, Kyushu Institute of Technology, 2-4 Hibikino, \\ Wakamatsu-ku, Kitakyushu, 808-0196, Japan
}

\section{Introduction}

Concentration quenching-based substrates have been developed for protease assays [1,2]. The substrate fluorescence is quenched by concentration quenching resulting from highly assembled fluorophores on the substrates. The release of these concentrated fluorophores by proteases leads to fluorescence recovery, thereby allowing detection of protease activity. In this study, we designed and synthesized model compounds as concentration quenching-based substrates. They are composed of two fluorescein isothiocyanates (FITCs) and one or two substrate peptides ( $\beta$-Ala-L-Ala-L-Phe-L-Ala) (Figure 1). Two types of concentration quenching-based substrates were designed: short-type substrates and long-type substrates. The short-type substrates are comprised of one FITC-linked substrate peptide and FITC on each edge of the core respectively. The long-type substrates are comprised of two FITC-linked substrate peptides. These substrates include hexamethylenediamine or ethylenediamine as the core.

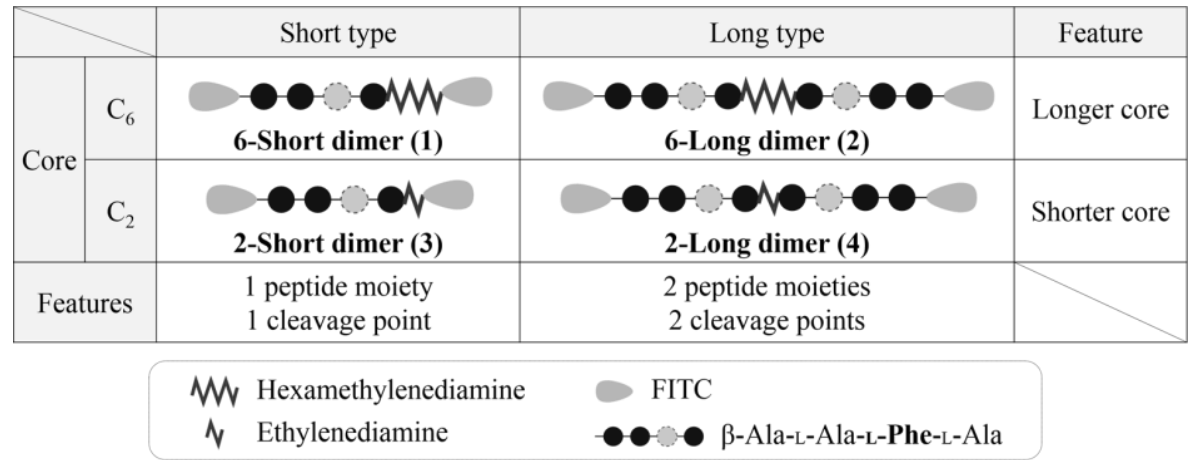

Fig. 1. Concentration quenching-based substrates developed in this study and their features.

\section{Results and Discussion}

For the synthesis of $\mathbf{1}$ and $\mathbf{3}$, the corresponding $N$-Boc-alkyldiamine was coupled with a Boc-protected peptide (Boc- $\beta$-Ala-L-Ala-L-Phe-LAla). FITC was then linked after the deprotection of the Boc group from the previously obtained compound. A similar synthetic route was applied to synthesize $\mathbf{2}$ and $\mathbf{4}$, using the corresponding unprotected diamine and the Boc-protected peptides.

First, the fluorescence spectra upon excitation at $495 \mathrm{~nm}$ of each substrate before the addition of chymotrypsin were measured. All of the substrate solutions were prepared as an equimolar solution of FITC $(1 \mu \mathrm{M})$ in $200 \mathrm{mM}$ Tris-HCl buffer with $5 \mathrm{mM}$ $\mathrm{CaCl}_{2}$ and $0.01 \%$ Tween $20(\mathrm{pH} \mathrm{8.0)}$. All of the substrates showed quenched fluorescence by intramolecular concentration quenching (Figure 2).

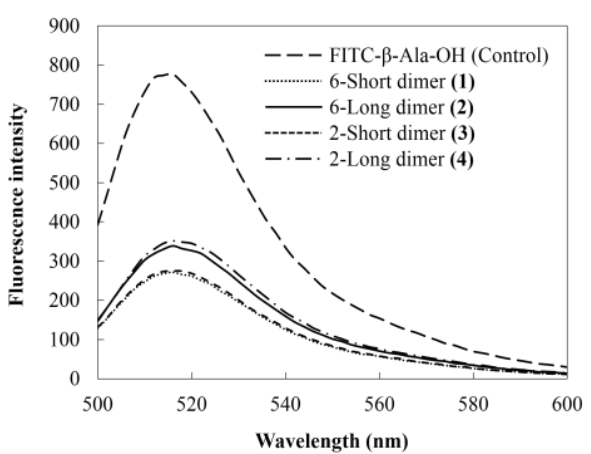

Fig. 2. Fluorescence spectra of each substrate prior to cleavage. 


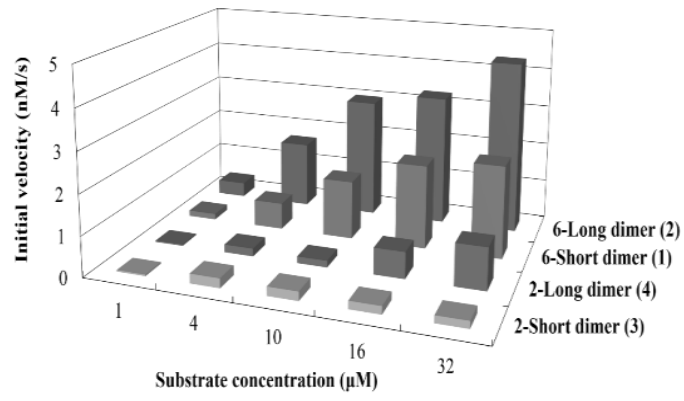

Fig. 3. Initial velocities of chymotrypsin cleavage.
Table 1. Quenching efficiencies of the substrates.

\begin{tabular}{cc}
\hline Substrate & Quenching efficiency \\
\hline 6-Short dimer (1) & $64 \%$ \\
6-Long dimer (2) & $52 \%$ \\
2-Short dimer (3) & $63 \%$ \\
2-Long dimer (4) & $55 \%$ \\
\hline
\end{tabular}

According to these spectral data, the quenching efficiencies were calculated (Table 1). The substrates with one peptide moiety had higher

quenching efficiency than the substrates with two peptide moieties. The differences in the length of the core barely affected the quenching efficiency.

Next, the increase in the fluorescence intensity at $535 \mathrm{~nm}$ upon excitation at $485 \mathrm{~nm}$ of different concentrations of substrates during chymotrypsin cleavage was monitored, and the initial velocities were calculated. The concentration of the substrates were prepared at $1,4,10,16$, and $32 \mu \mathrm{M}$, and the concentration of chymotrypsin was adjusted to $150 \mathrm{nM}$ with $50 \mathrm{mM}$ Tris- $\mathrm{HCl}$ buffer containing 100 $\mathrm{mM} \mathrm{NaCl}, 5 \mathrm{mM} \mathrm{CaCl}_{2}$, and $0.01 \%$ Tween 20 (pH 8.0). Compound 2 showed the fastest reaction rate of all the substrates. One explanation was that $\mathbf{2}$ had two cleavage sites for chymotrypsin compared with one site in 1, and was the least sterically hindered because of its longer core (Figure 3). Comparatively, compound $\mathbf{3}$, which possessed one peptide moiety and a shorter core, had the lowest initial velocity. This might be because $\mathbf{3}$ had only one cleavage site for chymotrypsin, and was sterically hindered. These observations were consistent with the $\mathrm{k}_{\text {cat }} / \mathrm{K}_{\mathrm{m}}$ values (Table 2$)$. The kinetic

Table 2. Kinetic parameters of chymotrypsin cleavage of each substrate.

\begin{tabular}{ccccc}
\hline Substrate & $\begin{array}{c}K_{m} \\
(\mu M)\end{array}$ & $\begin{array}{c}V_{\max } \\
(n M / s)\end{array}$ & $k_{\text {cat }}\left(s^{-1}\right)$ & $\begin{array}{c}k_{\text {cat }} / K_{m}\left(\mu M^{-1}\right. \\
\left.s^{-1}\right)\end{array}$ \\
\hline 6-Short dimer (1) & 13.1 & 3.41 & $2.27 \times 10^{-2}$ & $1.73 \times 10^{-3}$ \\
6-Long dimer (2) & 9.71 & 5.58 & $3.72 \times 10^{-2}$ & $3.83 \times 10^{-3}$ \\
2-Short dimer (3) & n.d. & n.d. & n.d. & n.d. \\
2-Long dimer (4) & n.d. & n.d. & n.d. & n.d. \\
\hline
\end{tabular}

n.d.: not determined. parameters of $\mathbf{3}$ and $\mathbf{4}$ could not be determined because the signal/noise $(\mathrm{S} / \mathrm{N})$ ratio was too low to calculate kinetic parameters reliably. These results indicate that the substrates consisting of two peptide moieties can be used for the detection of protease activity because of their faster reaction rates compared with the substrates consisting of one peptide moiety.

\section{References}

1. Ternon, M., Diaz-Mochon, J.J., Belsom, A., Bradley, M. Tetrahedron 60, 8721-8728 (2004), http://dx.doi.org/10.1016/i.tet.2004.05.105

2. Galande, A.K., Hilderbrand, S.A., Weissleder, R., Tung, C.-H. J. Med. Chem. 49, 4715-4720 (2006), http://dx.doi.org/10.1021/jm051001a 